\title{
APLIKASI SERAT ALAM BIDURI (Calotropis gigantea) SEBAGAI BAHAN PENGISI INSULATIF PADA JAKET MUSIM DINGIN
}

\author{
THE APPLICATION OF BIDURI NATURAL FIBER (Calotropis gigantea) AS AN \\ INSULATIVE FILLER MATERIAL IN WINTER JACKET
}

\author{
Arif Wibi Sana, ${ }^{1,2}$ Noerati Noerati, ${ }^{1}$ Doni Sugiyana, ${ }^{2}$ M. Danny Sukardan ${ }^{2}$ \\ ${ }^{1}$ Politeknik Sekolah Tinggi Teknologi Tekstil, Jalan Jakarta No. 31 Bandung \\ ${ }^{2}$ Balai Besar Tekstil, Jalan Jenderal Ahmad Yani No. 390 Bandung \\ Email: arif.wibi@yahoo.co.id
}

Tanggal diterima: 19 Maret 2020, direvisi: 28 Mei 2020, disetujui terbit: 8 Juni 2020

\begin{abstract}
ABSTRAK
Bahan pengisi insulatif komersial untuk jaket musim dingin umumnya menggunakan down (bulu angsa) dan batting poliester, tetapi penggunaannya relatif tidak ekonomis dan kurang ramah lingkungan. Serat biduri (Calotropis gigantea) merupakan serat alam dengan morfologi berongga dan ringan sehingga berpotensi menjadi bahan alternatif. Penelitian ini bertujuan untuk mempelajari sifat insulasi termal dan daya tembus udara pada kain multilapis berinsulasi biduri dan membandingkannya terhadap down dan batting poliester. Metode penelitiannya adalah dengan membentuk serat biduri menjadi web dan nonwoven yang difungsikan sebagai lapisan insulatif kemudian disisipkan di antara lapisan dalam (kain poliester) dan lapisan luar (kain nilon water repellent). Serat biduri diuraikan pada mesin bale opener kemudian dibentuk menjadi lapisan web pada mesin cotton selector. Pengikatan web menjadi nonwoven dilakukan dengan metode thermal bonding menggunakan mesin hotpress pada suhu $130{ }^{\circ} \mathrm{C}$ selama 1 menit tanpa perlakuan tekanan. Evaluasi dilakukan melalui pengujian menggunakan alat hotplate dan air permeability tester. Hasil penelitian menunjukkan bahwa nilai resistansi termal $\left(R_{c t}\right)$ tertinggi diperoleh pada kain multilapis berinsulasi web biduri $30 \mathrm{~g}$ dan nonwoven biduri tiga lapis pada komposisi (95:5)\% dengan nilai masing-masing sebesar $0,168 \mathrm{~m}^{2} .{ }^{\circ} \mathrm{C} / \mathrm{W}$ dan $0,188 \mathrm{~m}^{2} .{ }^{\circ} \mathrm{C} / \mathrm{W}$. Nilai tersebut masih lebih baik dibanding kain multilapis berinsulasi down dan batting poliester yang bernilai masing-masing $0,163 \mathrm{~m}^{2} .{ }^{\circ} \mathrm{C} / \mathrm{W}$ dan 0,160 $\mathrm{m}^{2} .{ }^{\circ} \mathrm{C} / \mathrm{W}$. Daya tembus udara (DTU) paling tinggi diperoleh pada kain multilapis berinsulasi batting poliester dengan nilai $6,34 \mathrm{~cm}^{3} / \mathrm{cm}^{2} / \mathrm{s}$ sedangkan paling rendah diperoleh pada nonwoven biduri 3 lapis-komposisi (80:20)\% dengan nilai $1,94 \mathrm{~cm}^{3} / \mathrm{cm}^{2} / \mathrm{s}$. Nilai $R_{c t}$ kain multilapis berinsulasi biduri meningkat seiring dengan peningkatan ketebalan sedangkan pada nilai DTU berlaku sebaliknya.
\end{abstract}

Kata kunci: insulasi panas, jaket musim dingin, kain multilapis, serat biduri

\begin{abstract}
The insulative filler materials commonly used on winter jackets are down and polyester batting. Biduri fiber (Calotropis gigantea) is a natural fiber with hollow morphology and lightweight so that it has a potency as an alternative material. The aim of this study is to determine the thermal insulation and air permeability of the biduri insulator applied in multilayer fabrics and compare them to down and polyester batting. Biduri fibers were formed into web and nonwoven, which functioned as an insulative layer then inserted between inner layer (polyester fabric) and the outer layer (nylon water repellent fabric). Biduri were processed on a bale opener and then formed into a web layer on a cotton selector machine. The nonwoven was later manufactured by thermal bonding using a hot press machine at $130{ }^{\circ} \mathrm{C}$ for 1 minute without pressure. The sample was tested using a hotplate and air permeability tester. The results showed that the best insulation properties were obtained in $30 \mathrm{~g}$ of biduri web and three layers of biduri nonwoven in a composition of (95:5)\% with thermal resistance values $\left(R_{c t}\right)$ of $0.168 \mathrm{~m}^{2} .{ }^{\circ} \mathrm{C} / \mathrm{W}$ and 0.188 $\mathrm{m}^{2} .{ }^{\circ} \mathrm{C} / \mathrm{W}$, respectively. This value is still better than down and polyester batting insulations, which are valued at $0.163 \mathrm{~m}^{2} .{ }^{\circ} \mathrm{C} / \mathrm{W}$ and $0.160 \mathrm{~m}^{2} .{ }^{\circ} \mathrm{C} / \mathrm{W}$. The air permeability of polyester batting was the highest with a value of 6.34 $\mathrm{cm}^{3} / \mathrm{cm}^{2} / \mathrm{s}$, while 3-layered of biduri nonwovens (80:20)\% was the lowest with a value of $1.94 \mathrm{~cm}^{3} / \mathrm{cm}^{2} / \mathrm{s}$. The insulation value of biduri on multilayer fabrics increased with the increase of thickness, whereas its air permeability applies in reverse.
\end{abstract}

Keywords: biduri fiber, multilayer fabric, thermal insulation, winter jacket 


\section{PENDAHULUAN}

Kekayaan alam yang dimiliki oleh Indonesia sangat melimpah, tetapi beberapa potensinya belum dimanfaatkan secara optimal. Salah satu keanekaragaman hayati berupa tanaman yang belum dieksplorasi lebih jauh dalam bidang tekstil adalah tanaman biduri. Tanaman ini merupakan jenis tanaman perdu dengan nama ilmiah Calotropis gigantea yang lebih dulu dikenal oleh masyarakat sebagai tanaman obat. ${ }^{1,2} \mathrm{Di}$ negara lain, tanaman tersebut ditemukan dalam spesies yang sama dan berbeda dengan nama milkweed, mudar, akund, rux, dsb. ${ }^{3-5}$ Sejumlah peneliti memanfaatkan beberapa bagian dari tanaman tersebut seperti biji, buah, daun, batang, akar, dan getah sebagai serat, ${ }^{6}$ penguat pada komposit, ${ }^{7-9}$ bahan baku obat, ${ }^{10}$ anti mikroba, ${ }^{11,12}$ enzim, ${ }^{13,14}$ bahan bakar, ${ }^{15}$ dan penyerap minyak. ${ }^{16,17}$ Beberapa spesies lain dari tanaman milkweed, yaitu Asclepias syriaca dan Calotropis procera sudah dikaji pemanfaatannya untuk pembuatan benang dan insulator. ${ }^{18,19}$ Di Indonesia, tanaman biduri masih luput dari perhatian masyarakat maupun pemerintah, sehingga diperlukan suatu upaya untuk mengeksplorasi potensi tanaman tersebut agar pemanfaatannya menjadi tepat guna dan bernilai ekonomis.

Tekstil fungsional adalah bahan atau pakaian yang dibuat secara khusus untuk memberikan fungsi tertentu kepada pengguna pada saat kondisi lingkungan di bawah atau di atas normal. ${ }^{20}$ Salah satu jenis tekstil fungsional adalah pakaian pelindung dari kondisi lingkungan berbahaya, misalnya panas atau dingin, api, hujan, salju, debu, angin, paparan sinar UV, zat kimia berbahaya, bakteri, virus, dsb. Jaket atau mantel merupakan salah satu pakaian pelindung yang biasa digunakan untuk melindungi penggunanya dari cuaca dingin. Di negara yang mengalami musim dingin, peran jaket berinsulasi panas memegang peranan penting untuk melindungi penggunanya dari cuaca dingin ekstrim yang dapat membahayakan jiwa manusia. ${ }^{21}$ Menurut data futuremarketinsights, ${ }^{22}$ segmen jaket memiliki market share yang paling besar dibandingkan segmen lain pada kelompok pakaian musim dingin dengan nilai share $48,2 \%$.

Jaket atau mantel musim dingin (winter jacket/coat) yang beredar di pasaran biasanya terbuat dari beberapa lapis bahan yang berfungsi menahan hawa dingin di luar sekaligus melindungi dari angin, hujan atau bahkan salju. Bahan pengisi insulatif biasanya berada pada lapisan tengah yang berfungsi menjaga panas tubuh agar tidak keluar. Bahan yang biasa digunakan adalah down (berasal dari bulu angsa atau bebek) dan bahan sintetis (biasanya terbuat dari filamen halus poliester yang dipotong pendek dan dibentuk menjadi bahan lembaran/batting). ${ }^{23}$
Menurut Beaudry (2017), ${ }^{24}$ down banyak diaplikasikan sebagai bahan pengisi insulatif pada jaket musim dingin karena bobotnya ringan, sifat insulasinya sangat baik, mudah dipadatkan, dan lebih tahan lama dibanding insulasi sintetis. Namun, kelemahannya adalah harganya mahal, sifat insulasinya akan menurun ketika terbasahi ${ }^{25}$ dan termasuk kategori bahan impor. Selain itu, down dapat memicu alergi (hypoallergenic), sehingga rentan apabila digunakan oleh penderita alergi. ${ }^{26}$ Beberapa kasus menyebutkan bahwa penggunaan down disoroti isu etika perlindungan terhadap hewan ketika diperoleh dengan cara pencabutan terhadap hewan hidup. Di sisi lain, bahan sintetis memiliki keunggulan dalam hal harga yang murah dan tahan terhadap kondisi basah, tetapi kelemahannya adalah agak berat, agak sulit dipadatkan, sedikit kurang tahan lama, sifat insulasinya yang tidak sebaik down, dan cenderung kurang ramah lingkungan karena berasal dari produk samping minyak bumi yang akan melepaskan gas rumah kaca. Oleh karena itu, diperlukan suatu bahan alternatif untuk mengatasi beberapa kekurangan tersebut.
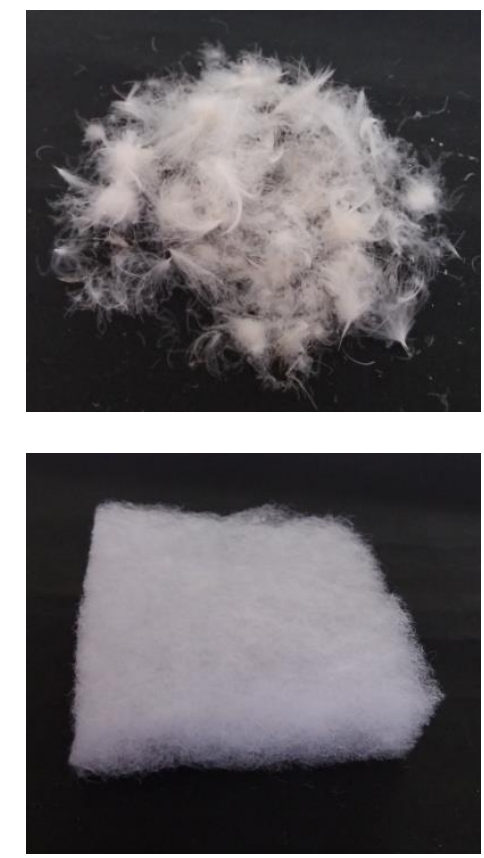

Gambar 1. Down (atas) dan batting poliester (bawah)

Serat biduri memiliki bentuk morfologi berongga (hollow), ${ }^{1,3}$ yang berfungsi sebagai media/perangkap udara sehingga aliran panas dapat ditahan oleh udara yang terperangkap pada rongga tersebut. Oleh karena itu, serat biduri berpotensi untuk dijadikan sebagai bahan insulasi panas alami, terbarukan, dan ramah lingkungan. Selain itu, serat ini tidak memicu alergi, ringan, dan tidak mudah terbasahi karena sifatnya yang hidrofobik. 

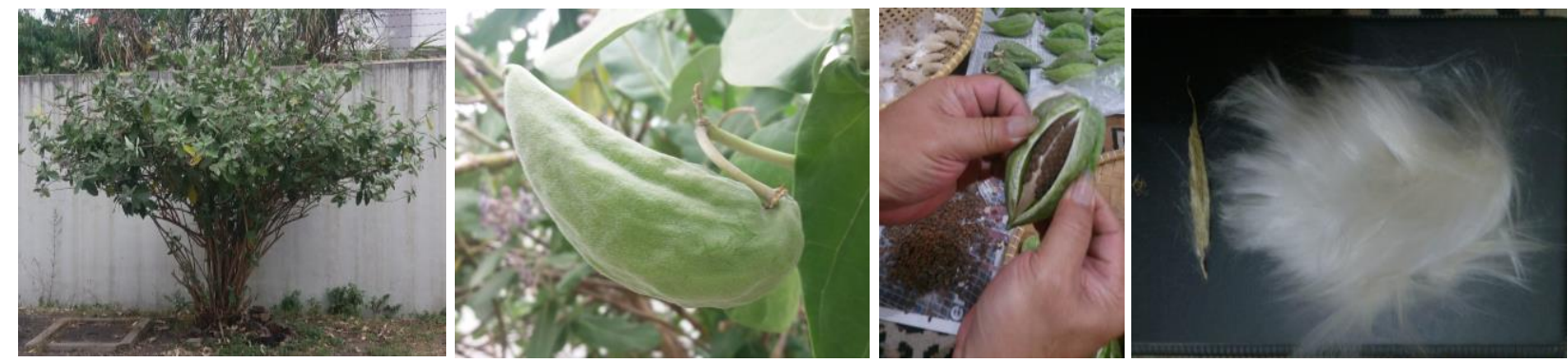

Gambar 2. Pohon, buah, biji dan serat biduri
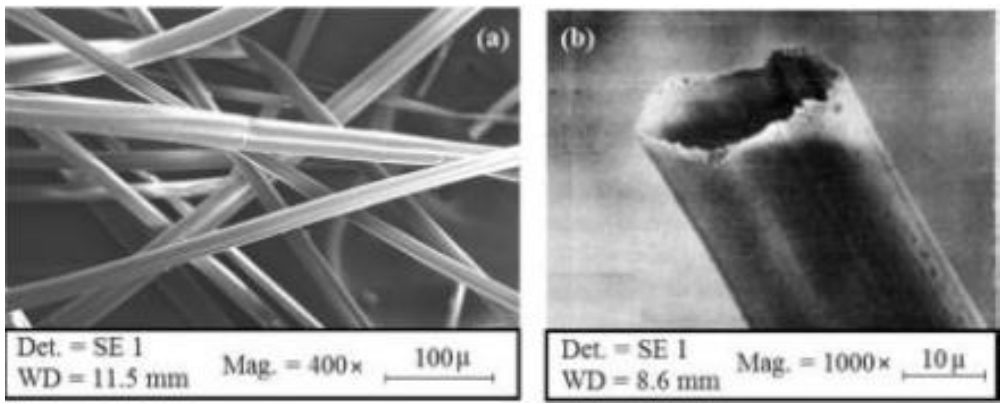

Gambar 3. Morfologi serat biduri: (a) penampang membujur, (b) penampang melintang ${ }^{3}$

Penelitian yang mengkaji tentang bahan pengisi insulatif pada jaket sudah dilakukan oleh Crews et al. (1991) dengan membandingkan 5 jenis jaket yang terbuat dari berbagai macam bahan insulasi, diantaranya serat milkweed (spesies Asclepias syriaca dan speciosa), down, campuran milkweed-down, campuran milkweed-bulu unggas serta poliester Quallofil. ${ }^{27}$ Mereka menyimpulkan bahwa bahan campuran antara serat milkweed dan down memiliki karakteristik insulasi yang sama dengan $100 \%$ down. Pada tahun 1999, Kasturiya et al. meneliti tentang desain pakaian musim dingin dan mengemukakan bahwa sistem yang efektif pada bahan kain jaket musim dingin adalah berupa susunan bahan multilapis yang terdiri dari lapisan dalam (bersentuhan dengan kulit), lapisan tengah (bahan insulasi panas), dan lapisan luar (tahan air dan breathable). ${ }^{28}$ Penelitian tentang perbandingan beberapa merk jaket musim dingin berbahan insulasi down dan sintetis juga pernah dilakukan oleh Steindhart (2015) dan menghasilkan kesimpulan bahwa down menghasilkan insulasi yang paling baik. ${ }^{29}$ Saat ini, produk jaket musim dingin dengan insulasi milkweed sudah mulai dikembangkan dalam skala kecil dan dipasarkan secara online oleh perusahaan start up di Kanada. ${ }^{30-}$

${ }^{32}$ Hingga saat ini, belum ditemukan penelitian yang mengkaji tentang pengembangan serat biduri sebagai bahan insulasi untuk aplikasi jaket musim dingin.

Pada penelitian ini, serat biduri dibentuk menjadi web dan nonwoven serta difungsikan sebagai bahan insulasi panas yang disisipkan sebagai lapisan tengah/pengisi pada kain multilapis. Tujuan yang ingin dicapai dari penelitian ini adalah mengetahui sifat insulasi termal dan daya tembus udara dari kain multilapis berisi serat biduri serta membandingkan performanya dengan down dan batting poliester sebagai bahan yang sudah lama digunakan untuk aplikasi jaket musim dingin sehingga diharapkan dapat menjadi bahan insulasi alternatif pengganti bahan hewani dan sintetis yang sudah lama eksis di pasaran.

\section{METODE}

\section{Bahan yang digunakan}

Serat biduri diperoleh dari biji yang berada pada bagian buah (pods) tanaman biduri yang tumbuh di sekitar halaman kantor Balai Besar Tekstil. Down diperoleh dari bahan pengisi jaket musim dingin merk The North Face - Summit Series. Batting poliester dan kain tenun poliester 100\% 60D beranyaman polos diperoleh dari salah satu toko bahan jaket. Low melt polyester (LMP) diperoleh dari PT Rekadaya Multi Adiprima. Kain tenun nilon 100\% 20D beranyaman polos dan sudah diberi perlakuan dengan water repellent diperoleh dari online market.

\section{Peralatan}

Peralatan yang diperlukan meliputi timbangan, loyang dan lembaran teflon, mesin cotton selector/trash analyzer Shirley Development Ltd tipe FM-30 C3, mesin bale opener, mesin hot press buatan BBT, serta mesin jahit merk Singer Model 8280.

\section{Pembuatan Lembaran Serat (Web) Biduri}

Pada tahap ini, serat biduri dipisahkan dari sisa biji, kotoran, dan debu yang tidak diperlukan dengan mengunakan mesin Cotton Selector (CS) sehingga diperoleh berkas 
serat biduri yang bersih. Tahap selanjutnya adalah membuat web biduri di mesin CS dengan massa asupan serat sebesar $10 \mathrm{~g}$ sebanyak 3 lembar. Variasi dibuat dengan penambahan jumlah lapisan web, yaitu : 1 lapis ( 1 x $10 \mathrm{~g}), 2$ lapis $(2 \times 10 \mathrm{~g})$, dan 3 lapis $(3 \times 10 \mathrm{~g})$ sehingga diperoleh 3 variasi dengan ketebalan yang berbeda.

\section{Pembuatan Nonwoven Biduri}

Pembuatan nonwoven biduri diawali dengan pencampuran serat biduri dan serat pengikat (binder) jenis low melt polyester (LMP) dengan variasi perbandingan komposisi (95:5)\%, (90:10)\%, dan $(80: 20) \%$. Total massa campuran serat dibuat sebesar $15 \mathrm{~g}$. Serat biduri dan LMP dicampur secara manual terlebih dahulu menggunakan tangan, dilanjutkan dengan pencampuran pada mesin bale opener sebanyak 3 kali proses sehingga diharapkan kedua jenis serat tersebut tercampur secara homogen. Kemudian campuran serat tersebut diproses pada mesin CS sehingga diperoleh berkas campuran serat berbentuk web. Selanjutnya web serat dikempa pada mesin hotpress pada suhu 130 ${ }^{\circ} \mathrm{C}$ selama 2 x 1 menit (dibolak-balik sisinya) tanpa tekanan tambahan, dengan jarak antar pelat penekan sebesar $5 \mathrm{~mm}$. Variasi dibuat dengan penambahan jumlah lapisan nonwoven, yaitu : 1 lapis, 2 lapis, dan 3 lapis sehingga diperoleh 3 variasi dengan ketebalan yang berbeda.

\section{Pembuatan Kain Multilapis}

Kain multilapis dibuat dengan bentuk segi empat berukuran $32 \mathrm{~cm}$ x $32 \mathrm{~cm}$ sedangkan bahan insulasi ukurannya dibuat sesuai dengan hasil keluaran produk pada mesin cotton selector dan hotpress. Susunan dari kain multilapis adalah sebagai berikut: ${ }^{33-35}$

1) Inner layer (lining), yaitu lapisan dalam yang bersentuhan dengan kulit yang terbuat dari kain poliester

2) Middle layer (insulation filler), yaitu lapisan tengah yang berisi bahan insulasi panas

3) Outer layer (shell), yaitu lapisan luar yang bersifat tahan air dan angin yang terbuat dari kain nilon water repellent.

Lapisan dalam dan luar dijahit terlebih dahulu di ketiga sisinya dengan menyisakan satu sisinya tanpa dijahit hingga menyerupai bentuk kantong. Setiap jenis bahan insulasi dimasukan kedalam sisi kantong yang terbuka kemudian dijahit untuk menutup sisi yang terbuka tersebut. Ilustrasi dari susunan kain multilapis diperlihatkan pada Gambar 4.

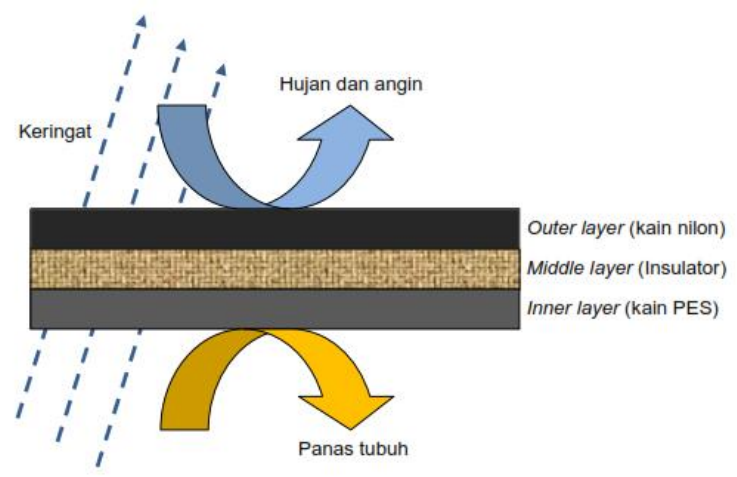

Gambar 4. Desain sampel kain multilapis

Desain percobaan dibuat berdasarkan variasi pada lapisan tengah (middle layer), meliputi jenis, massa, dan ketebalan bahan insulasi. Variasi percobaan dan kode sampel ditunjukan pada Tabel 1.

Tabel 1. Variasi percobaan

\begin{tabular}{|c|c|c|c|}
\hline $\begin{array}{c}\text { Jenis Bahan } \\
\text { Insulasi } \\
\text { (Middle Layer) }\end{array}$ & $\begin{array}{c}\text { Massa } \\
\text { Bahan } \\
(\mathrm{g})\end{array}$ & $\begin{array}{l}\text { Jumlah } \\
\text { Lapisan }\end{array}$ & $\begin{array}{c}\text { Kode } \\
\text { Sampel }\end{array}$ \\
\hline Down & 30 & 1 lapis & D1 \\
\hline Batting Poliester & 30 & 1 lapis & D2 \\
\hline \multirow{3}{*}{ Web Biduri } & 10 & 1 lapis & B1 \\
\hline & 20 & 2 lapis & B2 \\
\hline & 30 & 3 lapis & B3 \\
\hline \multirow{3}{*}{$\begin{array}{l}\text { Nonwoven Biduri- } \\
\text { LMP }(95: 5) \%\end{array}$} & 15 & 1 lapis & NW1 \\
\hline & 30 & 2 lapis & NW2 \\
\hline & 45 & 3 lapis & NW3 \\
\hline \multirow{3}{*}{$\begin{array}{l}\text { Nonwoven Biduri- } \\
\text { LMP (90: 10)\% }\end{array}$} & 15 & 1 lapis & NW4 \\
\hline & 30 & 2 lapis & NW5 \\
\hline & 45 & 3 lapis & NW6 \\
\hline \multirow{3}{*}{$\begin{array}{l}\text { Nonwoven Biduri- } \\
\text { LMP }(80: 20) \%\end{array}$} & 15 & 1 lapis & NW7 \\
\hline & 30 & 2 lapis & NW8 \\
\hline & 45 & 3 lapis & NW9 \\
\hline
\end{tabular}

Variasi B1, B2, dan B3 merupakan contoh uji kain multilapis berisi bahan insulasi yang terbuat dari serat biduri $100 \%$ berbentuk lembaran serat (web) dengan massa serat secara berturut-turut adalah $10 \mathrm{~g}$ (1 lapis), 2 x $10 \mathrm{~g}$ (2 lapis), dan 3 x $10 \mathrm{~g}$ (3 lapis).

Variasi NW1, NW2, dan NW3 merupakan contoh uji kain multilapis berisi bahan insulasi yang terbuat dari campuran serat biduri dan binder yang dibentuk menjadi bahan nonwoven dengan 
komposisi serat biduri $95 \%$ dan binder/low melt polyester (LMP) 5\%. Variasi NW4, NW5, dan NW6 merupakan nonwoven dengan komposisi serat biduri $90 \%$ dan LMP $10 \%$ sedangkan variasi NW7, NW8, dan NW9 merupakan nonwoven dengan komposisi serat biduri $80 \%$ dan LMP 20\%. Tiap komposisi dibuat menjadi 3 variasi ketebalan lapisan, 1 lapis (15 g), 2 lapis ( 2 x $15 \mathrm{~g}$ ), dan 3 lapis (3 x $15 \mathrm{~g})$.

D1 dan D2 merupakan kain multilapis pembanding berisi bahan insulasi down dan batting poliester, dengan jumlah massa asupan masingmasing $30 \mathrm{~g}$.

Hasil pembuatan web dan nonwoven serat biduri serta contoh uji kain multilapis diperlihatkan pada Gambar 5.
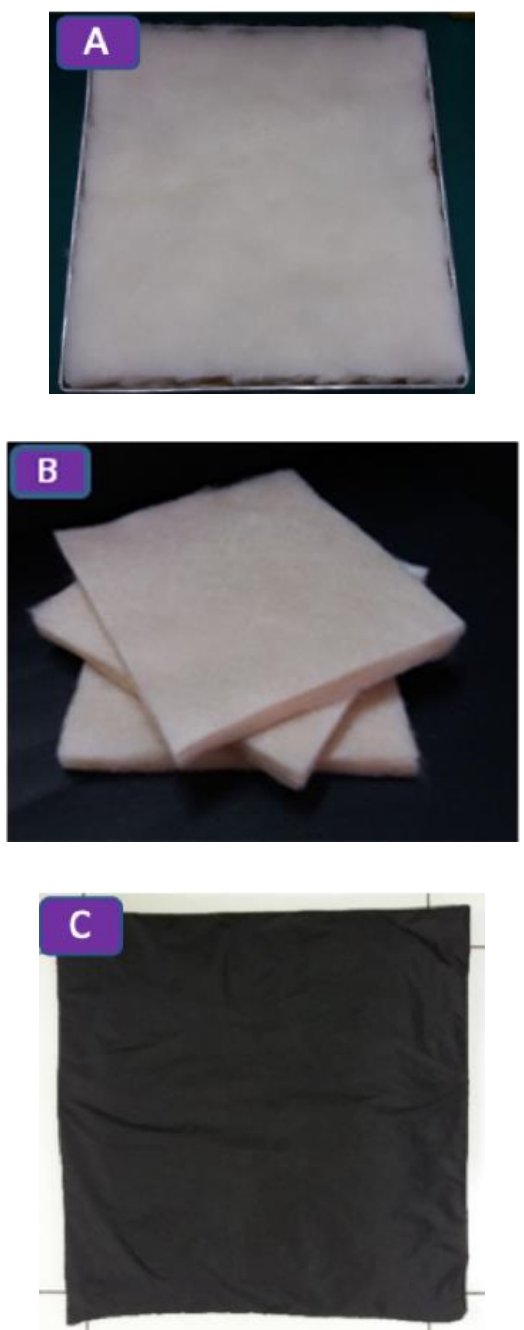

Gambar 5. Hasil pembuatan web serat biduri (A), nonwoven serat biduri (B) dan kain multilapis $(\mathrm{C})$

\section{Pengujian dan Evaluasi Kain Multilapis}

Sifat insulasi termal dievaluasi melalui pengujian resistansi termal menggunakan alat pelat pemanas (hotplate), pengukur suhu, pengukur daya, dan chamber yang dirakit dengan mengacu pada prinsip dan skema uji resistansi termal pada metode standar ASTM D1518-14. Prosedur pada standar tersebut dimodifikasi untuk menyesuaikan dengan karakteristik alat uji. Setiap alat ukur yang digunakan dalam sistem alat tersebut dikalibrasi terhadap alat standar. Validasi alat dilakukan menggunakan bahan yang sudah diketahui nilai konduktivitas termalnya. Nilai resistansi termal yang digunakan adalah nilai yang sudah dikalikan dengan faktor koreksi dari hasil validasi. Skema alat tersebut ditunjukkan pada Gambar 6.

Prinsip metode ini adalah mengukur perbedaan antara suhu permukaan suatu media penghasil panas yang menempel pada permukaan bawah contoh uji dan suhu di atas bahan tersebut, daya listrik yang digunakan setelah kondisi pengukuran stabil (steady state), serta luas area bahan yang menempel pada hot plate. Selanjutnya, nilai resistansi termal $\left(R_{c t}\right)$ dihitung berdasarkan persamaan berikut: ${ }^{36}$

$$
R_{c t}=\frac{A\left(T_{\Xi}-T_{a}\right)}{H_{C}}
$$

dimana,

$R_{c t} \quad$ : resistansi termal total $\left(\mathrm{m}^{2} .{ }^{\circ} \mathrm{C} / \mathrm{W}\right)$

$T_{s} \quad$ : penunjukan suhu termokopel yang menempel pada hotplate $\left({ }^{\circ} \mathrm{C}\right)$

$T_{a} \quad$ : penunjukan suhu termokopel di atas permukaan bahan $\left({ }^{\circ} \mathrm{C}\right)$

A : luas area bahan/contoh uji yang menempel pada hotplate $\left(\mathrm{m}^{2}\right)$

$H_{c} \quad$ : laju perpindahan panas yang sebanding dengan daya yang terbaca pada alat wattmeter $(\mathrm{W})$

Untuk mengetahui sejauh mana performa contoh uji kain multilapis dalam menahan udara dingin dari luar, dilakukan uji daya tembus udara dengan mengacu pada standar uji ASTM D737 menggunakan alat air permeability tester merek Textest Instruments, tipe FX 3300. 


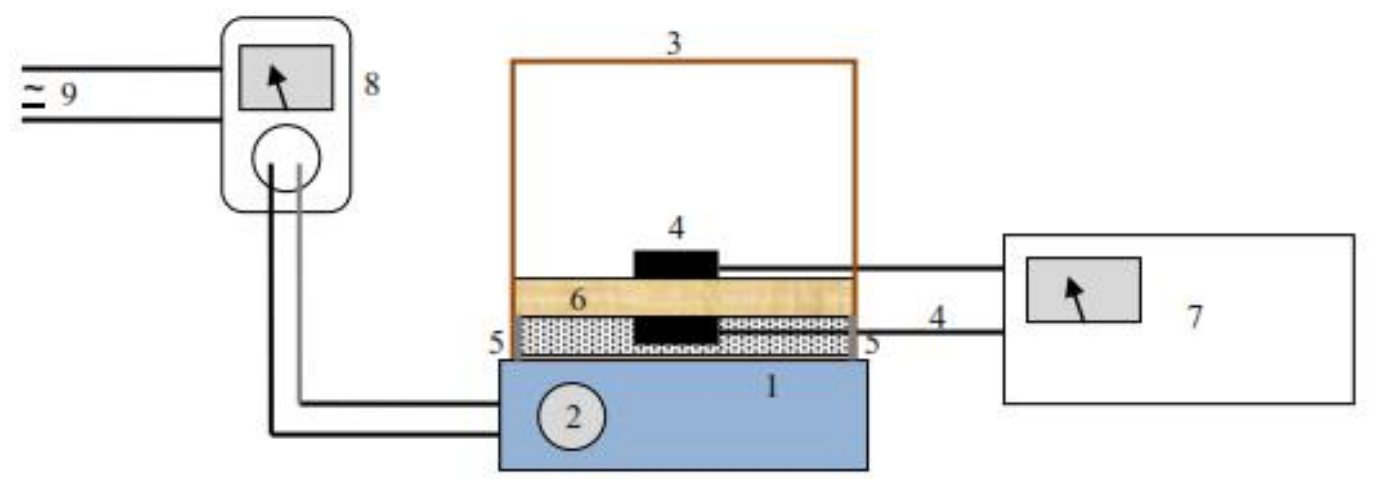

Gambar 6. Skema alat uji resistansi termal : (1) hotplate, (2) tombol pengatur suhu, (3) chamber, (4) sensor termokopel, (5) guard/insulator panas, (6) contoh uji, (7) multichannel thermometer recorder, (8) wattmeter, (9) sumber arus listrik AC

\section{HASIL DAN PEMBAHASAN}

\section{Hasil Uji Resistansi Termal}

Perbandingan performa beberapa bahan insulasi dapat dilihat pada data dan grafik nilai resistansi termal $\left(R_{c t}\right)$ yang ditampilkan pada Tabel 2 dan Gambar 7. Data hasil pengujian menunjukan bahwa nilai $R_{c t}$ pada bahan insulasi web biduri mengalami kenaikan signifikan seiring dengan kenaikan massa/gramasi dan ketebalan bahan insulasi. Pernyataan tersebut didukung dengan uji statistik ANOVA satu arah (menggunakan bantuan aplikasi SPSS) yang menunjukan bahwa nilai $R_{c t}$ dari ketiga variasi contoh uji tersebut dikategorikan berbeda secara signifikan dengan nilai signifikansi $(\mathrm{P}$-value $)=0,000(\alpha=0,05)$. Kenaikan nilai $R_{c t}$ dapat disebabkan oleh meningkatnya ketebalan seiring dengan pertambahan massa serat dan lapisan web. Komposisi serat biduri yang lebih banyak mengakibatkan bertambahnya rongga yang menjebak udara diam (still air) dalam bahan insulasi kain multilapis.
Menurut Fuller (2015), sebuah bahan dikategorikan memiliki sifat insulasi yang baik apabila memiliki karakteristik berpori dan berongga. ${ }^{25}$ Insulasi termal menunjukan kemampuan suatu bahan dalam menahan aliran panas. Beberapa literatur menyebutkan bahwa menurut Hukum Fourier, nilai insulasi termal akan sebanding dengan ketebalan bahan. ${ }^{37-42}$ Bila dibandingkan, web biduri memiliki nilai $R_{c t}$ yang lebih besar $\left(0,168 \mathrm{~m}^{2} . \mathrm{C} / \mathrm{W}\right)$ daripada down $(0,163$ $\left.\mathrm{m}^{2} . \mathrm{C} / \mathrm{W}\right)$ dan batting poliester $\left(0,160 \mathrm{~m}^{2} . \mathrm{C} / \mathrm{W}\right)$ pada massa yang sama $(30 \mathrm{~g})$. Fenomena tersebut dapat disebabkan oleh bentuk morfologi serat biduri yang berongga sehingga lebih banyak menjebak udara dan menahan aliran panas. Pernyataan tersebut didukung dengan uji ANOVA satu arah yang menunjukan bahwa semua contoh uji tersebut dikategorikan berbeda secara signifikan, dengan nilai signifikansi $(\mathrm{P}$-value $)=0,000(\alpha=0,05)$.

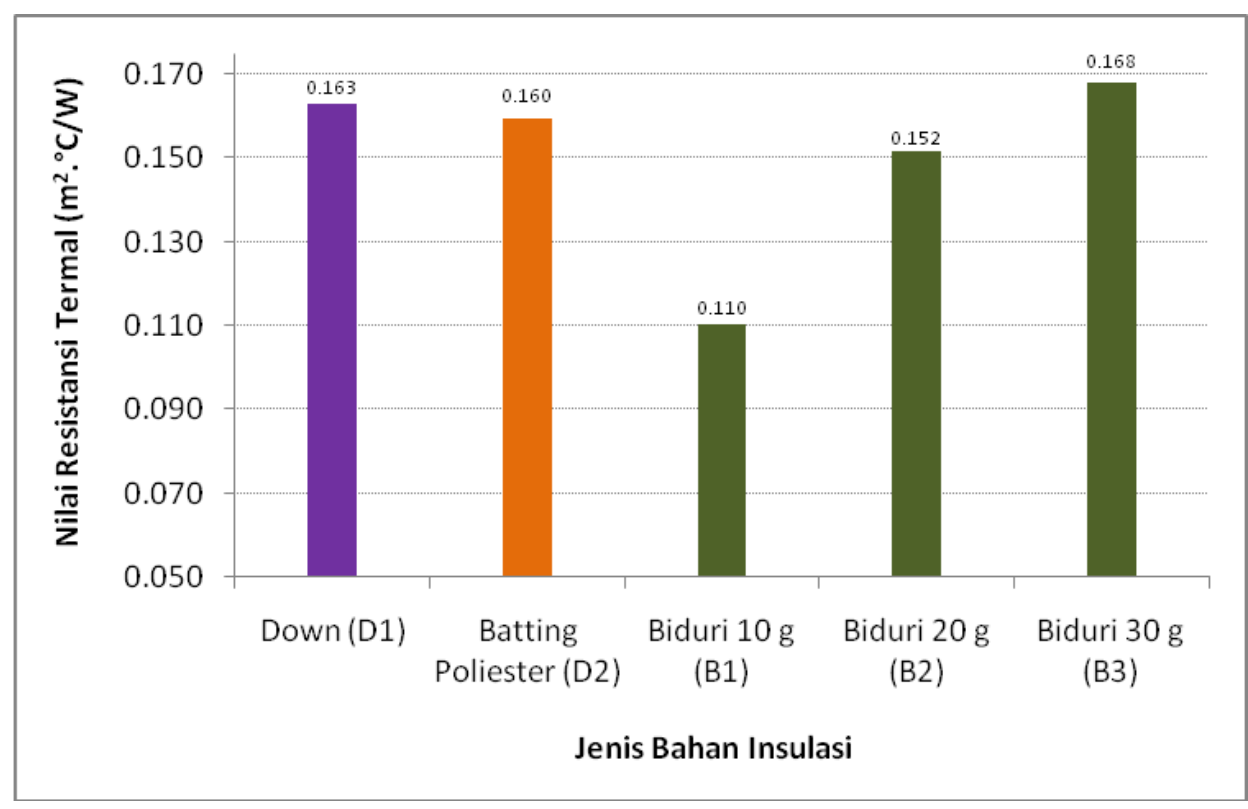

Gambar 7. Grafik nilai resistansi termal web biduri dan pembanding (down dan batting poliester) 
Perbandingan nilai $R_{c t}$ pada bahan insulasi nonwoven biduri dan pembanding ditampilkan pada Tabel 2 dan Gambar 8. Hasil pengukuran insulasi termal menunjukan bahwa nilai $R_{c t}$ pada bahan insulasi nonwoven biduri mengalami kenaikan signifikan seiring dengan kenaikan ketebalan lapisan. Pernyataan tersebut didukung dengan uji statistik ANOVA satu arah yang menunjukan bahwa nilai ketiga variasi contoh uji tersebut dikategorikan berbeda secara signifikan, dengan nilai signifikansi $(\mathrm{P}$-value $)=0,000(\alpha=0,05)$. Hal ini dapat disebabkan oleh meningkatnya ketebalan bahan. Penambahan lapisan nonwoven mengakibatkan perbedaan ketebalan pada nonwoven yang dihasilkan.

Menurut ISO 5085, nilai resistansi termal sebanding dengan ketebalan bahan (L) sehingga berkorelasi dengan hasil percobaan bahwa semakin tebal bahan insulasi maka semakin tinggi nilai insulasi termalnya.

$$
R=\frac{L}{k}
$$

Persamaan tersebut juga menunjukan suatu hubungan bahwa nilai resistansi termal berbanding terbalik dengan nilai konduktivitas termal $(k)$. Ini bermakna bahwa bila suatu bahan memiliki nilai konduktivitas termal lebih kecil maka daya insulasinya lebih besar. Bila dibandingkan dengan $R_{c t}$ down $\left(0,163 \mathrm{~m}^{2}\right.$.C/W) dan batting poliester $\left(0,160 \mathrm{~m}^{2} . \mathrm{C} / \mathrm{W}\right)$, maka nilai pada nonwoven biduri di semua variasi komposisi pada ketebalan 2 lapis dan 3 lapis cenderung lebih besar. Pada komposisi nonwoven $(95: 5) \%$ diperoleh nilai $R_{c t}$ pada ketebalan 2 dan 3 lapis masing-masing sebesar $0,175 \mathrm{~m}^{2}$.C/W dan $0,188 \mathrm{~m}^{2} . \mathrm{C} / \mathrm{W}$. Pada komposisi (90:10)\% diperoleh nilai $R_{c t}$ pada ketebalan 2 dan 3 lapis masing-masing sebesar $0,170 \mathrm{~m}^{2} . \mathrm{C} / \mathrm{W}$ dan $0,184 \mathrm{~m}^{2} . \mathrm{C} / \mathrm{W}$ sedangkan pada komposisi (80:20)\%, nilai $R_{c t}$ yang lebih besar daripada pembanding $\left(0,177 \mathrm{~m}^{2} . \mathrm{C} / \mathrm{W}\right)$ hanya diperoleh pada ketebalan 3 lapis. Data yang menunjukan nilai $R_{c t}$ yang lebih kecil adalah variasi dengan ketebalan 1 lapis di semua variasi komposisi dengan nilai $R_{c t}$ masing-masing sebesar $0,149 \quad \mathrm{~m}^{2} . \mathrm{C} / \mathrm{W}, \quad 0,147$ $\mathrm{m}^{2} . \mathrm{C} / \mathrm{W}$, dan 0,139 $\mathrm{m}^{2} . \mathrm{C} / \mathrm{W}$. Selain ketebalan, komposisi campuran biduri dan low melt polyester (LMP) juga berpengaruh pada nilai $R_{c t}$. Menurut literatur, densitas LMP $\left(1,35 \mathrm{~g} / \mathrm{cm}^{3}\right)$ lebih tinggi daripada serat biduri $\left(0,87 \mathrm{~g} / \mathrm{cm}^{3}\right)^{43}$ sehingga apabila jumlah komposisi LMP meningkat maka kemungkinan densitas bahan campuran akan meningkat. Semakin tinggi densitas suatu bahan, semakin sedikit udara yang terjebak di dalam rongga bahan sehingga kemungkinan nilai $R_{c t}$ juga akan semakin rendah. Data yang divisualisasikan pada Gambar 8 juga menunjukan terjadinya penurunan nilai resistansi termal seiring dengan kenaikan kandungan LMP dan penurunan kandungan serat biduri. Meskipun penurunannya tidak terlalu besar, tetapi secara statistik (uji ANOVA satu arah) dapat dikategorikan signifikan, dengan nilai signifikansi $(\mathrm{P}$-value $)=0,000(\alpha=$ $0,05)$.

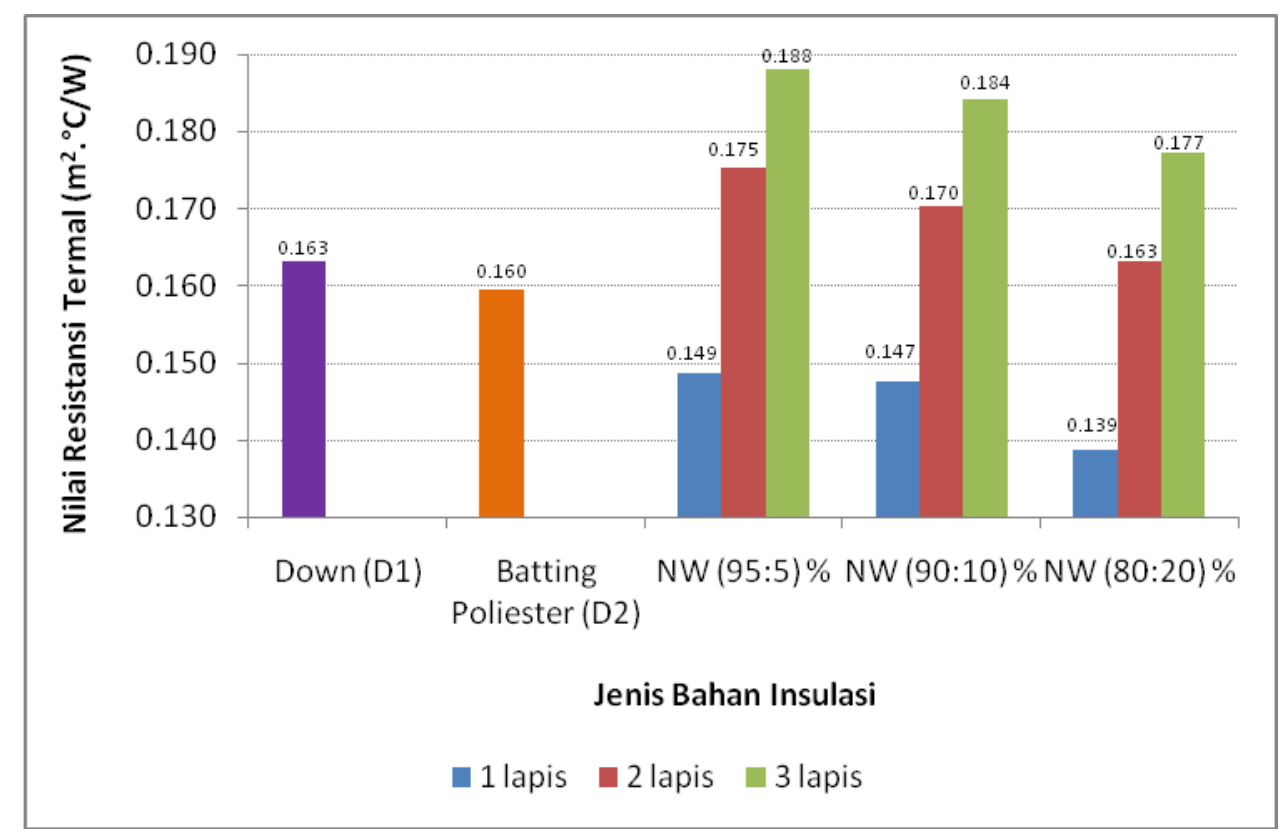

Gambar 8. Grafik hasil uji insulasi termal nonwoven biduri dan pembanding (down dan batting poliester) 


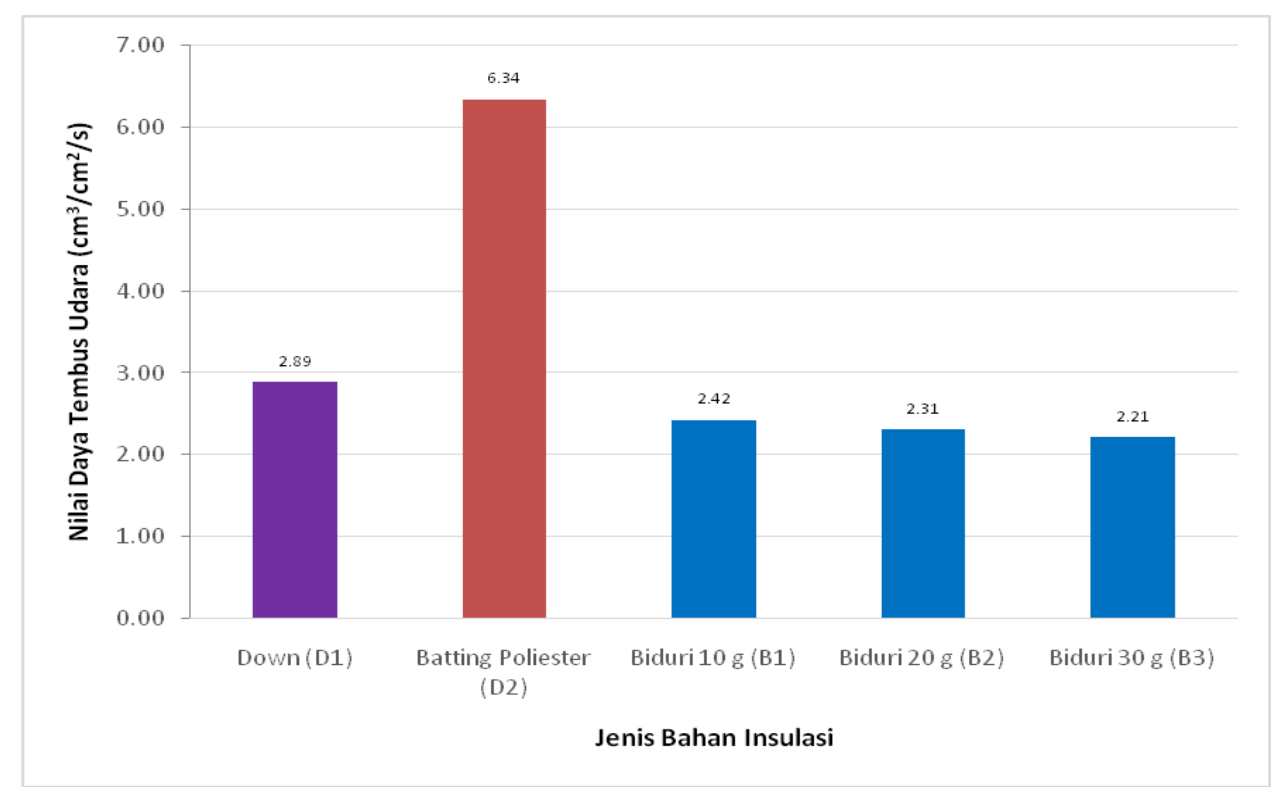

Gambar 9. Grafik hasil uji daya tembus udara web biduri dan pembanding (down dan batting poliester)

\section{Hasil Uji Daya Tembus Udara}

Hasil uji daya tembus udara pada contoh uji kain multilapis dengan bahan pengisi insulatif web biduri, yaitu variasi B1 (biduri $10 \mathrm{~g}$ ), B2 (biduri 20 $\mathrm{g}$ ), dan B3 (biduri $30 \mathrm{~g}$ ) yang diperlihatkan pada Tabel 2 dan divisualisasikan pada Gambar 9 memperlihatkan suatu tren bahwa kenaikan massa/gramasi serat dan ketebalan lapisan web contoh uji mengakibatkan penurunan nilai daya tembus udara. Hal ini dapat dipahami bahwa semakin banyak serat biduri dan semakin tebal lapisan web, semakin sulit bahan untuk ditembus sehingga kemampuan menahan aliran udara lebih besar dan volume udara yang lolos lebih kecil. Bila dibandingkan dengan down (D1) dan batting poliester (D2), terlihat bahwa nilai DTU pada semua variasi web biduri memiliki nilai yang lebih rendah $\left(2,42 ; 2,31 ;\right.$ dan $\left.2,21 \mathrm{~cm}^{3} / \mathrm{cm}^{2} / \mathrm{s}\right)$ daripada down $\left(2,89 \mathrm{~cm}^{3} / \mathrm{cm}^{2} / \mathrm{s}\right)$ dan batting poliester $(6,34$ $\left.\mathrm{cm}^{3} / \mathrm{cm}^{2} / \mathrm{s}\right)$. DTU paling kecil diperoleh pada contoh uji web biduri $30 \mathrm{~g}$. Berdasarkan uji ANOVA satu arah, nilai DTU pada semua variasi massa serat biduri dikategorikan tidak berbeda signifikan (P-value) $=0,181(\alpha=0,05)$, begitu pula bila dianalisa lebih lanjut dengan uji statistik Student Newman Keuls (SNK), terlihat bahwa nilai DTU pada massa asupan serat $10 \mathrm{~g}, 20 \mathrm{~g}$, dan $30 \mathrm{~g}$ berada pada subset/kelompok yang sama sehingga bisa dikatakan bahwa nilainya tidak berbeda signifikan. Secara keseluruhan, nilai DTU untuk semua contoh uji web biduri tergolong kecil.
Semakin kecil nilai DTU suatu bahan, semakin baik kemampuannya dalam menahan udara dari luar. Kontribusi paling besar dari perolehan nilai tersebut disebabkan oleh karakteristik salah satu jenis kain pelapis, yaitu kain nilon water repellent yang memiliki nilai DTU kecil dengan nilai 2,47 $\mathrm{cm}^{3} / \mathrm{cm}^{2} / \mathrm{s}$.

Hasil uji daya tembus udara pada contoh uji kain multilapis dengan bahan insulasi nonwoven biduri beserta down (D1) dan batting polyester (D2) ditampilkan pada Tabel 2 dan Gambar 10.

Pengaruh ketebalan dan gramasi nonwoven biduri terhadap nilai DTU dapat dilihat pada kelompok NW (95:5)\%, yang mencakup NW1 untuk ketebalan 1 lapis, NW2 (2 lapis), dan NW3 (3 lapis), kelompok NW (90:10)\%, yang mencakup NW4 (1 lapis), NW5 (2 lapis), dan NW6 (3 lapis), serta kelompok NW (80:20)\%, yang mencakup NW7 (1 lapis), NW8 (2 lapis), dan NW9 (3 lapis). Data yang divisualisasikan pada Gambar 10 memperlihatkan adanya tren penurunan nilai DTU seiring dengan kenaikan ketebalan dan gramasi bahan. Hal ini dapat dipahami bahwa semakin tebal bahan insulasi, semakin tinggi hambatan terhadap udaranya sehingga volume udara yang mengalir lebih kecil. Bila dibandingkan dengan down dan batting poliester, terlihat bahwa nilai DTU pada semua variasi nonwoven biduri memiliki nilai yang lebih rendah $(2,32 ; 2,22 ; 2,16 ; 2,25 ; 2,14 ; 2,05$; 2,$\left.20 ; 2,07 ; 1,94 \mathrm{~cm}^{3} / \mathrm{cm}^{2} / \mathrm{s}\right)$ daripada down $(2,89$ $\left.\mathrm{cm}^{3} / \mathrm{cm}^{2} / \mathrm{s}\right)$ dan batting poliester $\left(6,34 \mathrm{~cm}^{3} / \mathrm{cm}^{2} / \mathrm{s}\right)$. 


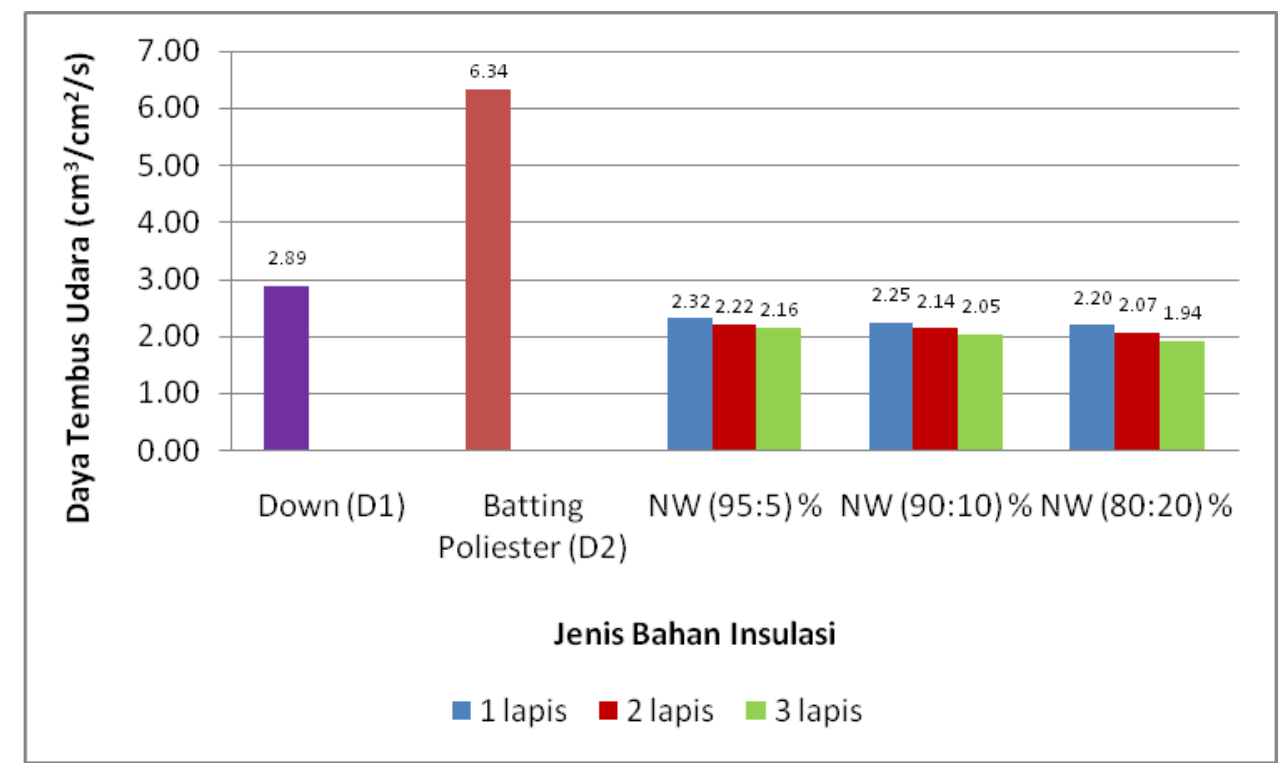

Gambar 10. Grafik hasil uji daya tembus udara nonwoven biduri dan pembanding (down dan batting poliester)

Tabel 2. Hasil karakterisasi contoh uji kain multilapis

\begin{tabular}{lrccc}
\hline \multicolumn{1}{c}{ Jenis Contoh Uji } & $\begin{array}{r}\text { Ketebalan* } \\
(\mathrm{mm})\end{array}$ & $\begin{array}{c}\text { Gramasi } \\
\left(\mathrm{g} / \mathrm{m}^{2}\right)\end{array}$ & $\begin{array}{c}\text { Resistansi } \\
\text { Termal }=R_{c t} \\
\left(\mathrm{~m}^{2} .{ }^{\circ} \mathrm{C} / \mathrm{W}\right)\end{array}$ & $\begin{array}{c}\text { Daya Tembus } \\
\text { Udara } \\
\left(\mathrm{cm}^{3} / \mathrm{cm}^{2} / \mathrm{s}\right)\end{array}$ \\
\hline Kain pelapis; nilon dan poliester (PL) & 0,16 & 115 & 0,075 & 2,43 \\
PL + Down (D1) & 8,32 & 410 & 0,163 & 2,89 \\
PL + Batting Poliester (D2) & 9,75 & 356 & 0,160 & 6,34 \\
PL + Biduri 10 g (B1) & 3,99 & 210 & 0,110 & 2,42 \\
PL + Biduri 20 g (B2) & 7,75 & 311 & 0,152 & 2,31 \\
PL + Biduri 30 g (B3) & 11,40 & 405 & 0,168 & 2,21 \\
PL + Nonwoven Biduri-LMP : 95\%-5\% (NW1) & 5,61 & 271 & 0,149 & 2,32 \\
PL + Nonwoven Biduri-LMP : 95\%-5\% (NW2) & 11,63 & 439 & 0,175 & 2,22 \\
PL + Nonwoven Biduri-LMP : 95\%-5\% (NW3) & 17,88 & 607 & 0,188 & 2,16 \\
PL + Nonwoven Biduri-LMP : 90\%-10\% (NW4) & 5,09 & 271 & 0,147 & 2,25 \\
PL + Nonwoven Biduri-LMP : 90\%-10\% (NW5) & 10,29 & 432 & 0,170 & 2,14 \\
PL + Nonwoven Biduri-LMP : 90\%-10\% (NW6) & 15,63 & 586 & 0,184 & 2,05 \\
PL + Nonwoven Biduri-LMP : 80\%-20\% (NW7) & 5,36 & 271 & 0,139 & 2,20 \\
PL + Nonwoven Biduri-LMP : 80\%-20\% (NW8) & 10,50 & 435 & 0,163 & 2,07 \\
PL + Nonwoven Biduri-LMP : 80\%-20\% (NW9) & 15,60 & 571 & 0,177 & 1,94 \\
\hline
\end{tabular}
*pada pembebanan $0,1 \mathrm{kPa}$.

Selain ketebalan dan gramasi, komposisi campuran serat biduri dan low melt polyester (LMP) juga berpengaruh pada nilai DTU. Densitas LMP lebih tinggi daripada serat biduri sehingga apabila jumlah komposisi LMP meningkat maka kemungkinan densitas/kerapatan bahan campuran ikut meningkat. Data yang divisualisasikan pada Gambar 10 juga menunjukan terjadinya penurunan nilai DTU seiring dengan kenaikan kandungan LMP dan penurunan kandungan serat biduri.

Berdasarkan uji ANOVA satu arah, nilai DTU semua contoh uji nonwoven dikategorikan berbeda secara signifikan (P-value) $=0,000(\alpha=$ $0,05)$, tetapi berdasarkan hasil uji statistik lanjutan Student Newman Keuls (SNK), terlihat bahwa nilai DTU pada variasi NW2, NW3, NW4, NW5, dan 
NW7 berada pada kelompok yang sama (subset 4) serta variasi NW6 dan NW8 berada pada kelompok yang sama (subset 2) sehingga bisa dikatakan bahwa variasi komposisi campuran nonwoven pada masing-masing kelompok tersebut menghasilkan nilai yang relatif sama secara statistik sedangkan variasi NW1 dan NW9 tidak termasuk ke dalam 2 subset tersebut.

Secara keseluruhan nilai DTU untuk semua contoh uji nonwoven biduri tergolong kecil. Semakin kecil nilai DTU suatu bahan, semakin baik kemampuannya dalam menahan udara dari luar. Sebagaimana dijelaskan dalam pembahasan sebelumnya bahwa kontribusi paling besar dari perolehan nilai tersebut disebabkan oleh karakteristik salah satu jenis kain pelapis, yaitu kain nilon water repellent yang memiliki nilai DTU kecil dengan nilai $2,47 \mathrm{~cm}^{3} / \mathrm{cm}^{2} / \mathrm{s}$.

\section{KESIMPULAN}

Dari penelitian ini dapat disimpulkan bahwa kain multilapis dengan bahan insulasi web biduri $30 \mathrm{~g}$ serta nonwoven biduri dengan tebal lapisan 2 lapis dan 3 lapis memiliki nilai insulasi termal $\left(R_{c t}\right)$ yang lebih tinggi dibanding down dan batting polyester. Selain itu, nilai daya tembus udara (DTU) kain multilapis dengan bahan insulasi web dan nonwoven biduri lebih rendah daripada down dan batting poliester sehingga diprediksi akan lebih kuat dalam menahan hembusan angin dingin yang berasal dari lingkungan luar. Nilai $R_{c t}$ kain multilapis berinsulasi biduri meningkat seiring dengan peningkatan ketebalan dan gramasi bahan sedangkan pada nilai DTU berlaku sebaliknya. Hasil uji tersebut dapat menggambarkan potensi serat biduri sebagai bahan pengisi insulatif pada jaket musim dingin. Bila dievaluasi berdasarkan sifat insulasi termal dan kemampuan menahan udara serta dengan mempertimbangkan biaya proses dan dampak terhadap lingkungan, maka kondisi optimum pada penelitian ini diperoleh pada kain multilapis dengan bahan pengisi insulatif web biduri $30 \mathrm{~g}$.

Perlu dilakukan studi lebih lanjut mengenai sifat breathability, durability, dan resiliency/lofty dari bahan pengisi insulatif biduri, terutama ketika berinteraksi dengan cairan, uap air atau kelembaban eksternal sehingga lebih meyakinkan saat diaplikasikan pada produk jaket musim dingin.

\section{PUSTAKA}

1. Sukardan, M. D., Natawijaya, D., Prettyanti, P., Cahyadi \& Novarini, E. Karakterisasi Serat dari Tanaman Biduri (Calotropis gigantea) dan Identifikasi Kemungkinan Pemanfaatannya sebagai Serat Tekstil. Arena Tekst. 31, 51-62 (2016).

2. Verma, V. N. The Chemical Study of Calotropis. Int. Lett. Chem. Phys. Astron. 20,
74-90 (2014).

3. Hassanzadeh, S. \& Hasani, H. A Review on Milkweed Fiber Properties as a High-Potential Raw Material in Textile Applications. J. Ind. Text. (2015) doi:10.1177/1528083715620398.

4. Karthik, T. \& Murugan, R. Milkweed - A Potential Sustainable Natural Fibre Crop. in Sustainable Fibres for Fashion Industry vol. 2 111-146 (2016).

5. Sakthivel, J. C. \& Mukhopadhyay, S. Some Studies on Mudar Fibers. J. Ind. Text. 35, 6376 (2005).

6. Zhao, Z. $d k k$. Pre-treatment of Calotropis gigantea fibers with functional plasticizing and toughening auxiliary agents. Text. Res. J. (2019) doi:10.1177/0040517519826885.

7. Dilli Babu, G., Sivaji Babu, K. \& Nanda Kishore, P. Tensile and wear behavior of calotropis gigentea fruit fiber reinforced polyester composites. Procedia Eng. 97, 531535 (2014).

8. Muniyasamy, S. Evaluation of Mechanical Properties of Calotropis Gigantea Stem FiberReinforced Composite Material. 53-57 (2016).

9. Sayanjali Jasbi, M., Hasani, H., Zadhoush, A. \& Safi, S. Effect of alkali treatment on mechanical properties of the green composites reinforced with milkweed fibers. J. Text. Inst. 109, 24-31 (2018).

10. Ghosh, A., Chakraverty, R. \& Sarkar, S. Calotropis Gigantea Linn. - A Complete Busket Of Indian Traditional Medicine. Int. J. Pharm. Res. Sci. 7, 1-17 (2014).

11. Kori, P. \& Alawa, P. Antimicrobial activity and phytochemical analysis of Calotropis gigantea root, latex extracts. IOSR J. Pharm. 4, 07-11 (2014).

12. Kumala, S. \& Pratiwi, A. A. Efek Antimikroba dari Kapang Endofit Ranting Tanaman Biduri. J. Farm. Indones. 7, 111-120 (2014).

13. Hardi, J. \& Diharnaini, D. Penggunaan Protease dari Getah Biduri dalam Produksi Flavor Udang Windu (Penaeus monodon) [Utilization of Protease from Biduri Sap for Production Windu Shrimp Flavor (Penaeus monodon)]. Online J. Nat. Sci. 3, 39-49 (2014).

14. Witono, Y. Enzim Biduri Agen Aktif Potensial Untuk Proses Pangan. (Pustaka Radja, 2013).

15. Phoo, Z. W. M. M. $d k k$. Evaluation of Indian milkweed (Calotropis gigantea) seed oil as 
alternative feedstock for biodiesel. Ind. Crops Prod. 54, 226-232 (2014).

16. Zheng, Y., Cao, E., Zhu, Y., Wang, A. \& Hu, H. Perfluorosilane treated Calotropis gigantea fiber: Instant hydrophobic-oleophilic surface with efficient oil-absorbing performance. Chem. Eng. J. 295, 477-483 (2016).

17. Zheng, Y., Zhu, Y., Wang, A. \& Hu, H. Potential of Calotropis gigantea fiber as an absorbent for removal of oil from water. Ind. Crops Prod. 83, 387-390 (2016).

18. Pusat Komunikasi Publik Kementerian Perindustrian. Rencana Induk Pembangunan Industri Nasional 2015 - 2035. 1-98 http://www.kemenperin.go.id/ripin.pdf (2015) doi:10.1017/CBO9781107415324.004.

19. Ali, M. E. \& Zeitoun, O. M. Discovering and Manufacturing a New Natural Insulating Material Extracted From a Plant Growing Up in Saudi Arabia. J. Eng. Fiber. Fabr. 7, 88-94 (2012).

20. Guptaa, D. Functional clothing- Definition and classification. Indian J. Fibre Text. Res. 36, 312-326 (2011).

21. Li, Y., Hsu, J. \& Fernie, G. Protective Winter Clothing. (2010).

22. Bauer, E. Winter Wear Market: Jackets / Coats Expected to be the Dominating Product Type During the Forecast Period: Global Industry Analysis ( 2013 - 2017 ) \& Opportunity. https://www.futuremarketinsights.com/reports/ winter-wear-market (2018).

23. Bolz, P. The Right Stuff for Cold Weather. vol. 1 (2005).

24. Beaudry, F. Sustainable Insulation for Winter Clothes.

https://www.thoughtco.com/sustainableinsulation-for-winter-clothes-4114611 (2017).

25. Fuller, M. E. The structure and properties of down feathers and their use in the outdoor industry. (The University of Leeds, 2015).

26. Siler, W. Could Humble Milkweed Replace Down Feathers In Your Outdoor Gear? https://gizmodo.com/could-humble-milkweedreplace-down-feathers-1698295598 (2009).

27. Crews, P. C., Sievert, S. A., Woeppel, L. T. \& Mccullough, E. A. Evaluation of Milkweed Floss as an Insulative Fill Material. Text. Res. J. 61, 203-210 (1991).

28. Kasturiya, N., Subbulakshmi, M. S., Gupta, S. C. \& Raj, H. System Design of Cold Weather
Protective Clothing. Def. Sci. J. 49, 457-464 (1999).

29. Steindhart, E. Determining an Easily Measured Factor of Merit for The Thermal Performance of Jackets. in Measurement and Instrumentation 1-7 (2015).

30. Bernstien, J. How a Quebec company used a weed to create a one-of-a-kind winter coat Canadians warm, help monarch butterflies. https://www.cbc.ca/news/canada/montreal/que bec-milkweed-winter-coat-1.3804138 (2016).

31. Hauss, E. The Natural Insulator of the Future : Asclepias Animal-friendly Insulation. http://altitude-blog.com/en/natural-insulatorfuture-asclepias/ (2019).

32. Montgomery, M. Possible world first : canadian winter coat uses renewable plant insulation.

http://www.rcinet.ca/en/2016/10/13/world-

first-canadian-winter-coat-uses-renewableplant-insulation/ (2016).

33. Baker, H. The Layering Systems. https://www.blacks.co.uk/blog/2016/09/thelayering-system-a16 (2018).

34. Oakes, J., Riewe, R., Kelker, D. \& Forest, T. Comparison of traditional and manufactured cold weather ensembles. vol. 5 (1995).

35. Zakriya, G. M. $d k k$. Design and development of winter over coat using Jute and hollow conjugated polyester non-woven flexible composite. J. Ind. Text. (2016) doi: $10.1177 / 1528083716670314$.

36. ASTM D1518-14. Standard test method for thermal transmittance of textile materials. vol. 94 428-430 (1985).

37. Song, G. Thermal insulation properties of textiles and clothing. Textiles for cold weather apparel (Woodhead Publishing Limited, 2009). doi:10.1533/9781845697174.1.19.

38. Rossi, R. M. Cold Weather sports clothing. in Textiles for Sportswear (ed. Shisoo, R.) 197212 (Woodhead Publishing Limited, 2015).

39. Rees, W. H. The transmission of heat through textile fabrics. J. Text. Inst. Trans. 32, T149T165 (1941).

40. Williams, J. T. Textile for cold weather apparel. (Woodhead Publishing Limited, 2009).

41. Baxter, S. The thermal conductivity of textiles. Proc. Phys. Soc. (1946) doi:10.1088/09595309/45/4/304. 
42. Holmer, I. Textiles for protection against cold. in Textile for protection (ed. Scott, R. A.) 378 397 (Woodhead Publishing Limited, 2005).

43. Sukmawati, A. Pembuatan dan Karakterisasi
Nirtenun Serat Biduri (Calotropis gigantea) untuk Aplikasi Bahan Penyerap Bunyi. (Tesis Program Magister Ilmu dan Teknik Material, Institut Teknologi Bandung, 2018). 